\title{
Investment in Education and Health: Lessons for the Growth Potentials in the COVID-19 Era
}

\author{
Ubong E. Effiong*
}

Department of Economics, University of Uyo, P.M.B. 1017, Uyo, Akwa Ibom State, Nigeria

\author{
DOI: $10.36348 /$ sjef.2020.v04i10.002 \\ | Received: 27.09.2020 | Accepted: 12.10.2020 | Published: 16.10 .2020
}

*Corresponding author: Ubong E. Effiong

\section{Abstract}

The negative effect of the Covid-19 pandemic on the growth potential of the economy, as it affects the health and educational sector serves as an inspiration for this paper to examine the effect of government expenditures on education and health on the economic growth of Nigeria. The study utilized data from the Central Bank of Nigeria statistical bulletin, World Development Indicators, and the Nigeria Centre for Disease Control (NCDC). The dependent variable was gross domestic product, while the explanatory variables include gross fixed capital formation, labour force, and government expenditure on education, government expenditure on health, broad money supply, inflation rate, and exchange rate. The data were analysed using the Bounds test for cointegration and error correction mechanism to investigate both the short run and long run relationship. The Bounds test revealed the existence of a long run relationship between government expenditures on education and health and economic growth. Further, the error correction model revealed that both government expenditures on education and health exert positive and significant effect on economic growth both in the short run and in the long run. The coefficient of the error correction term $(0.5833)$ indicates that $58.33 \%$ of the short run disequilibrium is corrected annually. The paper concludes by stating that Nigeria needs to invest massively on the education and health sector so as to make provisions for the necessary infrastructures that could be required for their smooth operations in this period of global pandemic and beyond.

Keywords: Economic Growth, Human Capital Development, Government Expenditures, Co-integration, Education, Health, Covid-19.

Copyright () 2020 The Author(s): This is an open-access article distributed under the terms of the Creative Commons Attribution 4.0 International License (CC BY-NC 4.0) which permits unrestricted use, distribution, and reproduction in any medium for non-commercial use provided the original author and source are credited.

\section{INTRODUCTION}

The role of the government in promoting economic growth was pronounced right from the mercantilist doctrine of trade protectionism until the classical economist led by Adam Smith pronounced and promoted laissez faire economic system. This doctrine gained weight over centuries until the Great Depression of the 1930s forced a new dimension to the management of the economy. The Keynesian revolution therefore gained weight and prompted the role of the government in managing the economy through aggressive spending in the time of depression and a reduction in such spending in the time of boom. This economic management practices have been described as fiscal policy to economic management.

The role of the government in promoting economic growth in the country cannot be overemphasised though the classicalist described its role as being inefficient and wasteful. The government on her part can employ strategic expenditure on crucial aspect of the economy so as to derive the desired benefit. Based on the human capital development perspective, government expenditure on human capital development is far more beneficial than investment in physical capital thus; expenditures on education and health are keen to promoting sustainable economic growth in a country.

Education and health are crucial for a nation's sustainability. Taking education for instance, it is the mental skills that are transferred to the creation and operation of physical capital hence, human intelligence is duly transferred to machines before a functional operation can be achieved. Education is crucial in the development of any society. As noted by [1], improving the education of people is not only a goal in itself for a better quality of life but also its positive impact on the economic development of a country is far-reaching. Also, education remains an end in itself and a means for achieving other goals of development like economic 
growth, poverty reduction, improved health care, great equity and reduced fertility [2].

Health on its on part is wealth. A wealthy workforce is likely to exhibit greater productivity as expressed in the production function of a nation. Improvement in health status of the citizenry is an important prerequisite for achieving human capital development in every economy with its multiplier effect in skilful, efficient and productive investment in human capital that will translate into economic development [3] cited in [4].

Both expenditures on education and health are seen as being crucial in human capital development which is important in the economic growth of any nation. This made [5] to incorporate human capital in the study of economic growth under the neoclassical framework. This theory of growth was based on the accumulation of factor inputs which include physical and human capital [6]. The theory views exogenous demographic factors such as population growth rate, labour force and the rate of technical change as being the determinants of long term equilibrium growth rate in the economy.

Investment in education and health have present itself to be crucial in this period of Covid-19 pandemic. The pandemic which have caused economic turmoil in the Nigerian economy in particular and the world in general. Our educational system has been put on hold due to lack of adequate infrastructure to support e-learning, making students/pupils to be out of school during the lockdown. The inadequacy of health infrastructures presented itself also, when the country was faced with the challenge of isolation centres and key personal protection equipment (PPE). This is followed by insufficient number of health workers especially the doctors. There is just one doctor for every 5,100 Nigerians - and they are not paid very well [7]. Also, the health sector is characterised by less budgetary allocation which hampers its robustness in ensuring adequate health care services to the populace. As at 2015, the number of hospitals stood at 23,640 [8] servicing more than 200 million people, with a $3.91 \%$ budgetary allocation to the sector as at 2018 [9]. These dwindling status of the health system points to the fact that Nigeria has not sufficiently invested in the health sector.

According to the Nigeria Centre for Disease Control (Oct. 1, 2020), the number of Covid-19 confirmed cases stood at 59,001 with 50,452 cases discharged; 1,112 deaths; and 7,437 active cases as at $1^{\text {st }}$ October 2020. This implies that out of a total of 509,555 samples tested as at that date, $11.59 \%$ came out to be positive. However, testing just 509,555 out of a population of over 200 million therefore becomes worrisome on the true state of the virus in the country. Out of this number of confirmed cases, a greater proportion concentrates on the economic hub of the country such as Lagos (33.12\%) and the Federal Capital Territory $(9.69 \%)$.

The real sector of the Nigeria economy has witnessed severe shock as a result of the pandemic. The economy experienced a $6.1 \%$ decline in output in the second quarter of 2020; with a forecast $3.2 \%$ decline at the end of the year. A successful management of the pandemic and development of possible cure will be a green light to Nigeria's economic recovery. Thus, investment in the health sector is crucial for this to be achieved. The educational system could also be revamp if adequate infrastructure is put in place to device means for a successful academic exercise while giving due attention to the Covid-19 laid down procedures. The sector will also aid in the provision of research findings that will help in the fight against the virus. In this way, investment in education and health will help the Nigeria economy to return to normalcy by the very possible moment. This study therefore seeks to investigate the effect of investment on education and health on economic growth of the country. The study specifically aims at examining the effect of government expenditure on health and education on the gross domestic product of Nigeria.

\section{LITERATURE REVIEW}

Human capital theories have been utilized in explaining the linkages between human capital development and economic growth. The theory views human capital as the stock of economically productive capabilities, which can be formed by combining innate abilities with investments in human beings [11]. Such investment involves expenditures on education, on-thejob-training, health, and nutrition. The importance of human capital development has been emphasized by the neoclassical growth theorist. With output (Y) defined as a function of capital (K) and labour (L),

$\mathrm{Y}=\mathrm{f}(\mathrm{K}, \mathrm{L})$

This neoclassical model as developed by [12] is augmented by [5] to capture the role of human capital, expressed as:

$\mathrm{Y}=\mathrm{K}, \mathrm{H},(\mathrm{AL})$

Where $\mathrm{Y}, \mathrm{K}$, and $\mathrm{L}$ are as defined above; and $\mathrm{H}$ and $\mathrm{A}$ are human capital and productivity coefficient respectively. Thus, an increase in the stock of human capital will throttle economic growth.

Empirical studies on the effect of human capital on economic growth have been carried out by several researchers over the years [13]. Examined the long-run relationship between education and economic growth in Nigeria using the Johansen co-integration approach as a frame work of analysis. The study revealed the existence of a long run relationship 
between enrolment in primary and tertiary levels of education and the average years of schooling with output per worker.

Examined the effect of human capital components on economic growth in Nigeria using the OLS and observed a positive and significant effect of human capital development, in terms of expenditure on health and education, on economic growth [14].

Also, [15] utilized the cointegration approach and the Granger causality test to investigate the effect of human capital development on economic growth in Nigeria. The study revealed that there is a long run relationship between public expenditures on education and economic growth. Also, the Granger causality test revealed that expenditure on education Granger cause economic growth.

Bakare, A. S. and Olubokun, S. [16] investigated the effect of health expenditures on economic growth in Nigeria. The study showed that there exists a positive and significant effect of health expenditures on economic growth.

Akintunde, T. S. and Satope, B. F. [17] in his attempt to examine the effect of human capital development and economic growth utilized the Vector Error Correction Mechanism. Their findings showed that there exists a long run relationship between health expenditure and economic growth. Also, health expenditure has a positive and significant effect on economic growth. Similarly, [18] observed that health indicators have a long run impact on economic growth.

Using panel regression analysis, [19] examined the effect of health outcomes on economic growth in developing countries. The study is of the view that improvement in life expectancy has a positive effect on economic growth in developing countries.

In Ethiopia, [20] utilized the ARDL approach to cointegration and the error correction mechanism to study the effect of government expenditure on education and health on economic growth. The findings of the study revealed that there exists a long run relationship and that government expenditure on education and health significantly affect economic growth. However, [21] observed a negative impact of both capital and recurrent expenditure on education on economic growth.

A study by [22] utilized the cointegration approach, error correction mechanism, and Granger causality test. They observed that there exists a long run effect between government expenditure on education and economic growth. Also, the Granger causality test revealed that both government capital and recurrent expenditures Granger cause economic growth.

Finally, [4] examined the effect of government expenditure on health on the quality of life in Nigeria. The study employed the Autoregressive Distributed Lag (ARDL) model and observed that government expenditure on health have a significant positive effect on life expectancy in Nigeria.

\section{METHODOLOGY}

This study employs an econometric approach in examining the effect of human capital development on economic growth of Nigeria. The study utilizes the cointegration approach and the error correction mechanism in achieving such feat. The model for the study is specified as follows:

$\mathrm{GDP}=\mathrm{f}(\mathrm{K}, \mathrm{L}, \mathrm{GE}, \mathrm{GH}, \mathrm{MS}, \mathrm{INF}, \mathrm{EXC})$

Transforming Equation (3) into its estimable form and linearizing the function by introducing logarithm yields;

$\log \mathrm{GDP}=\beta_{0}+\beta_{1} \log \mathrm{K}+\beta_{2} \log \mathrm{L}+\beta_{3} \log \mathrm{GE}+\beta_{4} \log \mathrm{GH}$ $+\beta_{5} \log \mathrm{MS}+\beta_{6} \mathrm{INF}+\beta_{7} \mathrm{EXC}+\mu-(4)$

Where:

GDP = real gross domestic product

$\mathrm{K}$ = gross fixed capital formation (a proxy for capital)

$\mathrm{L}=$ labour force (a proxy for labour)

$\mathrm{GE}=$ government expenditure on education

$\mathrm{GH}=$ government expenditure on health

MS = broad money supply

$\mathrm{INF}=$ consumer price index (a proxy for inflation)

$\mathrm{EXC}=$ exchange rate

$\log =$ natural logarithm

$\beta_{0}$ to $\beta_{7}=$ parameters to be estimated

$\mu=$ the random error term.

Transforming Equation (4) into an error correction model yields,

$\Delta \operatorname{logGDP} P_{t}=\beta_{0}+\sum_{i=1}^{m} \beta_{1} \Delta \log K_{t}+\sum_{i=1}^{m} \beta_{2} \Delta \log L_{t}+\sum_{i=1}^{m} \beta_{3} \Delta \operatorname{logGE_{t}}+\sum_{i=1}^{m} \beta_{4} \Delta \operatorname{logGH_{t}}+\sum_{i=1}^{m} \beta_{5} \Delta \operatorname{logMS}_{t}+\sum_{i=1}^{m} \beta_{6} \Delta \mathrm{INF}_{\mathrm{t}}+\sum_{\mathrm{i}=1}^{\mathrm{m}} \beta_{7} \Delta \mathrm{EXC}_{\mathrm{t}}+\lambda \mathrm{ECT}_{\mathrm{t}-1}+\mu_{\mathrm{t}}-(5)$

Where $\lambda$ captures the speed of adjustment of the short run disequilibrium and $\mathrm{ECT}_{(\mathrm{t}-1)}$ is the error correction term. The coefficient of the ECT $(\lambda)$ must be negative and statistically significant before such adjustment is regarded to be error correcting.
The error correction model is estimated after the null hypothesis of no cointegration is rejected. Under the ARDL framework, such test for cointegration is conducted using the Bounds test for levels relationship. If the F-statistic of the Bounds test is statistically significant, then cointegration exists. 
Data for the study were all obtained from secondary sources. Specifically, gross domestic product (GDP), government expenditure on education (GE), government expenditure on health $(\mathrm{GH})$, broad money supply (MS), and exchange rate (EXC), were obtained from the Central Bank of Nigeria Statistical Bulletin; while Gross fixed capital formation $(\mathrm{K})$, labour force (L), and inflation rate (INF) were obtained from the
World Development Indicators. the data are obtained for the period 1986 to 2018 .

\section{EMPIRICAL FINDINGS AND DISCUSSION}

The result of the Bounds test for cointegration is presented in Table 1 .

Table-1: Bounds Test for Levels Relationship

\begin{tabular}{|l|l|l|l|l|}
\hline \multicolumn{2}{|l|}{ F-Bounds Test } & \multicolumn{4}{l|}{ Null Hypothesis: No levels relationship } \\
\hline Test Statistic & Value & Significance & $\mathrm{I}(0)$ & $\mathrm{I}(1)$ \\
\hline F-statistic & 11.105 & $10 \%$ & 1.99 & 2.94 \\
\hline $\mathrm{k}$ & 7 & $5 \%$ & 2.27 & 3.28 \\
\hline & & $2.5 \%$ & 2.55 & 3.61 \\
\hline & & $1 \%$ & 2.88 & 3.99 \\
\hline
\end{tabular}

Source: Extracted from Eviews 10.

From Table 1, $\mathrm{K}$ denotes the number of parameters estimated which turns out to be 7 . The null hypothesis for the test is that there is no levels relationship, implying that there is no cointegration. Meanwhile, the F-statistic (11.105) is greater that both the lower I(0) and upper I(1) bounds. This implies that it is significant at the $5 \%$ level of significance. The implication here is that the null hypothesis of no levels relationship is therefore rejected hence, there is cointegration. The existence of cointegration leads to the estimation of the error correction model of which the result is presented in Table 2 .

Table-2: Short Run Error Correction Model Result

\begin{tabular}{|l|l|l|l|l|}
\hline$\Delta \operatorname{logK}$ & 0.0070 & 0.0074 & 0.9385 & 0.3651 \\
\hline$\Delta \operatorname{logK}(-1))$ & 0.0271 & 0.0077 & 3.5149 & $0.0038^{* * *}$ \\
\hline$\Delta \operatorname{logL}$ & 0.1268 & 0.0329 & 3.8506 & $0.0005 * * *$ \\
\hline$\Delta \log \mathrm{MS}$ & 0.2363 & 0.0422 & 5.5955 & $0.0001 * * *$ \\
\hline$\Delta \log \mathrm{GH}$ & 0.0357 & 0.0163 & 2.1916 & $0.0472 * *$ \\
\hline$\Delta \log \mathrm{GH}(-1))$ & 0.0395 & 0.0132 & 2.9761 & $0.0107 * *$ \\
\hline$\Delta \operatorname{logGE}$ & 0.0337 & 0.0147 & 2.2871 & $0.0396 * *$ \\
\hline$\Delta \log \mathrm{GE}(-1))$ & 0.0265 & 0.0111 & 2.3758 & $0.0336^{* *}$ \\
\hline$\Delta \mathrm{INF}$ & -0.0008 & 0.0002 & -3.4352 & $0.0044 * *$ \\
\hline$\Delta \mathrm{INF}(-1))$ & 0.0012 & 0.0002 & 4.5440 & $0.0006 * *$ \\
\hline$\Delta \mathrm{EXC}$ & -0.0007 & 0.0001 & -4.4451 & $0.0007 * * *$ \\
\hline ECT(-1) & -0.5833 & 0.0071 & -11.690 & $0.0000 * * *$ \\
\hline R-squared $=0.8342$ & \multicolumn{5}{|c|}{ Durbin-Watson Statistic $=1.549$} \\
\hline
\end{tabular}

Note: $* * *$ and $* *$ denotes significance at the $1 \%$ and $5 \%$ level respectively Source: Output Extracted from Eviews 10.

The coefficient of the adjusted short run dynamics is presented in Table 2. From the result, both government expenditure on education and health are growth promoting. They indicate a positive and significant effect on economic growth at the $5 \%$ level of significance. Thus, a unit percentage increase in government expenditure on health will lead to a $3.57 \%$ increase in economic growth in the short run. Also, a unit percentage increase in government expenditure in education will exert a $3.37 \%$ increase in economic growth. The one-period lag of both government expenditures on education and health also exerts a positive and significant effect on economic growth. Hence, a one-period lag of government expenditure on health increases economic growth by $3.95 \%$. Similarly, a one-period lag of government expenditure on education increases economic growth by $2.65 \%$.
Other variables in the model such as broad money supply and labour force are also observed to exert positive and significant effect on economic growth. A unit percentage increase in labour force will yield a $12.68 \%$ increase in economic growth; while a unit percentage increase in broad money supply result to a $23.63 \%$ increase in economic growth. However, inflation and exchange rate yields a negative and significant effect on economic growth. A unit percentage increase in inflation rate will prompt a $0.08 \%$ decline in economic growth; while a unit percentage increase in exchange rate will lead to a $0.07 \%$ decrease in economic growth in Nigeria.

The error correction term (ECT) is negative and statistically significant as expected. The coefficient of the ECT (0.5833) is an indication that $58.33 \%$ of the 
short run disequilibrium is corrected annually to arrive at long run equilibrium. The $\mathrm{R}$-squared is an indication that $83.42 \%$ of the variations in economic growth is explained by variations in the explanatory variables. The Durbin-Watson statistic (1.549) is approximately 2 and it shows that there is no serial correlation. From the short run error correction, the long run result is presented in Table 3.

Table-3: Long Run Result

\begin{tabular}{|l|l|l|l|l|}
\hline $\operatorname{logMS}$ & $\mathbf{- 0 . 1 5 1 5}$ & $\mathbf{0 . 0 8 3 1}$ & $\mathbf{- 1 . 8 2 1 8}$ & $\mathbf{0 . 1 2 8 1}$ \\
\hline $\log \mathrm{L}$ & 6.3901 & 0.6873 & 9.2962 & $0.0002^{* * *}$ \\
\hline $\log \mathrm{K}$ & -0.0759 & 0.0469 & -1.6168 & 0.1668 \\
\hline $\log \mathrm{GH}$ & 0.5330 & 0.0865 & 6.1592 & $0.0016^{* * *}$ \\
\hline $\log \mathrm{GE}$ & 0.8594 & 0.0771 & 11.1414 & $0.0001^{* * *}$ \\
\hline $\mathrm{INF}$ & 0.1112 & 0.1500 & 0.7413 & 0.4588 \\
\hline $\mathrm{EXC}$ & -0.0037 & 0.0005 & -6.7636 & $0.0011^{* * *}$ \\
\hline $\mathrm{C}$ & -96.205 & 11.243 & -8.5562 & $0.0004 * * *$ \\
\hline
\end{tabular}

Note: $* * *$ and $* *$ denotes significance at the $1 \%$ and $5 \%$ level respectively

Source: Output Extracted from Eviews 10.

In the long run, both government expenditures on education and health still exert a positive and significant effect on economic growth in Nigeria. Thus, a unit percentage increase in government expenditure on health will lead to a $53.30 \%$ increase in economic growth. Similarly, a unit percentage increase in government expenditure on education will lead to an $85.94 \%$ increase in economic growth. This is an indication that investment in human capital is key for a sustainable economic growth of any nation.

Meanwhile, labour force exerts a positive and significant effect on economic growth in the long run; while exchange rate exerts a negative and significant effect. Thus, a unit percentage increase in labour force yields a $6.39 \%$ increase in economic growth, while a unit percentage increase in exchange rate will lead to a $0.004 \%$ decrease in economic growth. Broad money supply and inflation rate are observed to exert an insignificant effect on economic growth in the long run.

\section{CONCLUSION}

The Covid-19 pandemic has revealed to Nigeria that there is need for massive investment on the education and health sectors. This study was an attempt to examine the effect of government expenditures on education and health on economic growth of Nigeria for the period 1986 to 2018. The study utilized the Bounds test for cointegration and error correction mechanism. The result shows that government expenditure on education has a positive effect on economic growth of Nigeria both in the short run and in the long run. Also, government expenditure on health exerts a positive and significant effect on the economic growth of Nigeria both in the short run and in the long run. With this, Nigeria needs to invest massively on the education and health sector so as to make provisions for the necessary infrastructures that could be required for their smooth operations in this period of global pandemic and beyond. Government should increase its expenditure on education up to the United Nations' recommendation of $26 \%$ of the total expenditure so as to warrant a boost of the sectorial outcomes. The more education that is applied to research and development, the faster new activities are generated, and the higher the rate of growth [23]. Also, the government should apportion $15 \%$ of her total budget to the health sector in line with the implementation of the 2001 World Health Organization (WHO) recommendation. In this way, our health sector will be able to adequately manage emergence of any pandemic as well as efficiently and effectively serving the basic health care needs of the populace. Going by the words of [24], health should not only be viewed as the absence of illnesses; it is also the ability of people to develop to their potential during their entire lives. As such, health affects economic growth directly through labour productivity and the economic burden of illnesses.

\section{REFERENCE}

1. Rebelo, S. (1991). Long-run policy analysis and long-run growth, Journal of Political Economy, 99(3).

2. Gleivwe, N., \& Illias, V. (1996). Determinants of school attainment in Sub-Sahara Africa: A case study of China. Journal of international development, 8(3), $395-413$.

3. Olarinde, M. O. and Bello, A. A. (2014). Public healthcare expenditure and health sector performance in Nigeria: Implications for sustainable economic development. IOSR Journal of Economics and Finance (IOSR-JEF), 4(3), 39 55.

4. Effiong, U. E., \& Bassey, E. B. (2020). Public health expenditure and the quality of life in Nigeria: An Empirical investigation. International Journal of Research and Sustainable Development, $7(1), 35-51$.

5. Mankiw, N. G., Romer, D., \& Weil, D. N. (1992). A contribution to the empirics of economic growth. Quarterly Journal of Economics, 107(2), 407 - 437.

6. Hiro, I., \& Huggins, R. (2004). Impact of education and training third report on vocational training research institute in Europe: background report. Luxembourg: Office for Official Publication of European Communities, Cedefop Reference Series, 54.

7. World Health Organization. (2015). World health statistics. Available www.who.int $>$ gho>publications

8. Pharm Access Foundation. (2018). Annual Accounts.

9. Budget Office of the Federation. (2018). Budget of the Federal Republic of Nigeria.

10. Nigeria Centre for Disease Control. (2020). Progression of Covid-19 cases in Nigeria. 
11. Aigbedion, I. M. (2015). The impact of human capital on development on economic growth. Research on Humanities and Social Sciences, $5(11), 39-49$.

12. Solow, R. (1957). Technical change and the aggregate production function. Review of Economics and Statistics, 6(39), 312 - 329.

13. Babatunde, M. A., \& Adefabi, R. A. (2005). Longrun relationship between education and economic growth in Nigeria: Evidence from Johannes's cointegration approach. Paper presented at the regional conference on education in West Africa: Constraints and opportunities. Dakar Senegal.

14. Augustine, U, (2009). Human capital development and economic growth: evidence from Nigeria. International Journal of Development Studies, 4(3), $80-85$.

15. Omijimite, B. U. (2010). Education and economic growth in Nigeria: Granger Causality analysis. International Multidisciplinary Journal, Ethiopia, 4(3a), $90-108$.

16. Bakare, A. S., \& Olubokun, S. (2011). Health care expenditure and economic growth in Nigeria: empirical study. Journal of Emerging Trends in Economics and Management Sciences, 2(2), 83 87.

17. Akintunde, T. S., \& Satope, B. F. (2013). Effect of health investment on economic growth in Nigeria. Journal of Economics and Finance, 1(2), 39 - 47.
18. Idowu, D. O. (2014). The impact of health on economic growth in Nigeria. Journal of Economics and Sustainable Development, 5(19), 159 - 166.

19. Ngangue, N., \& Manfred, K. (2015). The impact of life expectancy on economic growth in developing countries. Asian Journal of Economic and Financial Review, 5(4), 653 - 660.

20. Gebrehiwot, K. G. (2013). The impact of human capital development on economic growth in Ethiopia: evidence from ARDL approach to cointegration. A Thesis Submitted to the Department of Economics, Institute of Public Management and Development Studies, School of Graduate Studies, Ethiopian Civil Service University.

21. Ojewumi, J. S., \& Oladimeji, W. O. (2016). Effect of public spending on the growth of educational sector in Nigeria. JORIND, 14(2).

22. Inimino, E. E., Tubotamuno, B., \& Shaibu, D. O. (2017). Public education expenditure and economic growth in Nigeria. IIARD International Journal of Economics and Business Management, 3(6), 42 57.

23. Romer, P. M. (1990). Human capital and growth: Theory and evidence. Carnegie- Rochester Conference Series on Public Policy.

24. Lustig, N. (2001). Macroeconomics and health: Investing in health for economic development. Geneva: World Health Organization Publication. 